\title{
Surgical treatment of esophageal leiomyoma: an analysis of our experience
}

\author{
P. Priego, E. Lobo, G. Rodríguez, N. Alonso, M. A. Gil Olarte, J. Pérez de Oteyza and V. Fresneda \\ Department of General Digestive Surgery. Hospital Ramón y Cajal. Madrid, Spain
}

\begin{abstract}
Introduction: leiomyoma is the most common benign esophageal neoplasm. Surgical treatment (enucleation) has traditionally been the therapy of choice. The advent of minimally invasive techniques has produced an increase in endoscopic approaches to the detriment of open surgery.

Objective: the aim of this study was to compare the results obtained with open surgery and with laparoscopic surgery in this kind of pathology.

Material and methods: we performed a retrospective study of all leiomyomas operated for in our center between 1986 and 2004, and obtained 9 cases of esophageal leiomyoma. Four were women and five men, between the ages of 40 and 70, with a mean age of 53.5 years. The most frequent symptoms were heartburn (5 cases), dysphagia (3 cases), and retrosternal pain (3 cases). Surgery was in all the cases an enucleation. An open approach was performed in 5 cases (3 thoracotomies and 2 laparotomies), and an endoscopic approach in 4 (2 thoracoscopies and 2 laparoscopies).

Results: the mean postoperative hospital stay was 5.12 days (range 2-8 days). This was shorter for endoscopic approaches versus open surgery (3.25 vs. 7 days). There was no case of esophageal mucosal perforation or reconversion. No death, intraoperative complication, or tumor relapse was described. Only 2 patients had complications: post-surgical thoracic pain, and intestinal obstruction by adhesions 8 years after surgery.

Conclusion: enucleation is an easier procedure and constitutes the therapy of choice for esophageal leiomyoma. This approach has to be laparoscopic. We think that muscle borders should be closed after enucleation, and that biopsy is not indicated preoperatively.
\end{abstract}

Key words: Esophageal leiomyoma. Enucleation. Thoracoscopy. Laparoscopy. Thoracotomy. Benign tumor.

Recibido: 29-06-05.

Aceptado: 24-11-05.

Correspondencia: Pablo Priego Jiménez. C/ Fermín Caballero, 26, $1^{\circ} \mathrm{A}$. 16004 Cuenca.e-mail: papriego@ hotmail.com
Priego P, Lobo E, Rodríguez G, Alonso N, Gil Olarte MA, Pérez de Oteyza J, Fresneda V. Surgical treatment of esophageal leiomyoma: an analysis of our experience. Rev Esp Enferm Dig 2006; 98: 350-358.

\section{INTRODUCTION}

Leiomyoma is the most common benign esophageal neoplasm. Incidence is variable, and in autopsy series ranges from 0.005 to $5.1 \%$. Leiomyoma is relatively rare when compared with esophageal carcinoma, which occurs 50 times more frequently.

Morgagni first described leiomyoma in 1761, but Munro, in 1797, was the first to report a localized intramural leiomyoma of the esophagus.

Leiomyoma has traditionally been classified within the term of gastrointestinal stromal tumor (GIST); however, recent advances in immunohistochemical and molecular biology have suggested that these two conditions are different.

Symptoms, when present, are generally nonspecific and longstanding, and the treatment of these tumors is enucleation.

Sauerbruch reported in 1932 the first successful surgical treatment of leiomyoma with esophageal resection, and one year later Oshawa performed the first successful surgical enucleation of this type of tumor.

Surgical treatment has been performed by laparotomy or thoracotomy. However, the advent of minimally invasive techniques has produced an increase in endoscopic approaches to the detriment of open surgery.

The aim of this study is a retrospective analysis of hospital experience with this kind of pathology, and compare the results obtained for open an laparoscopic surgery. 


\section{MATERIAL AND METHODS (Table I)}

Between 1986 and 2004 we treated 9 cases of esophageal leiomyoma at the "Hospital Ramón y Cajal". Four were women and five were men, between the ages of 40 and 70 years, with a mean age of 53.5 years.

Five of these tumors were found in the distal third of the esophagus $(56 \%)$, three in the middle third $(33 \%)$, and one in the proximal third (11\%). Size of the tumors was $1-8 \mathrm{~cm}$, with a mean size of $3.4 \mathrm{~cm}$. There was no case of multiple leiomyoma, and all had an intramural localization.

The definitive anatomopathological diagnosis was in all cases esophageal leiomyoma except for one case of esophageal duplication cyst. We observed the typical aspect of leiomyomas with their firm consistency, white color, well encapsulated nature, and smooth or nodular surface. Histologically we saw smooth-muscle cells with hypovascularity and absent mitoses.

The most common symptoms included heartburn in 5 cases (56\%), dysphagia in $3(33 \%)$, and epigastric-retrosternal pain in 3 cases (33\%). Two patients had symptoms of upper GI blood (melena and duodenal ulcus); one reported regurgitation, and one rectorrhagia. There were only two asymptomatic patients (duodenal ulcus and rectorrhagia), which represents approximately $22.2 \%$, and one case was intraoperatively diagnosed during antireflux surgery.

Diagnostic studies before surgery included: oral endoscopy $8 / 9(88.8 \%)$, barium swallow $9 / 9(100 \%)$, thoracoabdominal CT $4 / 9$ (44.4\%), breath test $4 / 9$ cases (44.4\%) mainly in cases with a thoracic approach (thoracotomy and thoracoscopy), endoscopic ultrasonography 3/9 (33\%), abdominal ecography 3/9 (33\%), manometry $3 / 9(33 \%)$, and pH-metry $2 / 9(22.2 \%)$.

A biopsy was performed in 3 patients before surgery, and no tumor was found in any of them. In two cases it was performed by endoscopic ultrasonography, and in one case by $\mathrm{CT}$.

A hiatal hernia was found in four patients (44.4\%).

We performed 5 open surgeries ( 3 thoracotomies and 2 laparotomies), and 4 laparoscopic surgeries (2 thoracoscopic and 2 laparoscopic). If we analyze results after 2000 , we see a greater use of minimal invasive surgery, with 4 endoscopic approaches and one thoracotomy.

For thoracic approaches intubation was performed using a double-lumen endobronchial tube; the patient was placed in a left lateral decubitus position, and we usually entered the pleural cavity with 4 trocars.

For the abdominal laparoscopic approach we applied the same technical principles as for esophageal hiatal surgery.

In two cases -thoracoscopic approaches- we performed an intraoperative endoscopy to check tumor localization.

In all cases the esophageal mucosa was complete after checking in one case with methylene blue and in one case with an air injection through a nasogastric tube.
We sutured muscular defects in all cases.

In 4 cases we associated an antireflux technique (Dor's in 3 cases and Nissen's in one case). In contrast, we performed a simultaneous cholecistectomy in one case.

\section{RESULTS}

The mean operating time was 182.14 minutes (70-270 $\mathrm{min})$. For open surgery it was 146.25 minutes (70-205 $\mathrm{min}$ ), and 230 minutes for laparoscopic surgery (165-270 $\mathrm{min}$ ).

The mean postoperative hospital stay was 5.12 days (range 2-8 days). When comparing postoperative hospital stay between the laparoscopic approach and open surgery, a reduced stay (3.25 vs. 7 days) was seen in the group with laparoscopic approach.

There was no case of mortality or intraoperative complications. There was no case of conversion to open surgery either.

There was no case of recurrent leiomyoma.

Regarding postoperative complications: we have a patient with severe pain in the right hemithorax (operated by thoracoscopy) who requires periodic control at the Pain Unit, and another case of intestinal obstruction by adhesions eight years after surgery (laparotomy).

Two patients were re-operated on for reflux symptoms (both had previous surgery), and underwent a Nissen's procedure. Case number 5 was operated on 11 months after first surgery, and case number 9 at 8 months. In both cases the approach was laparoscopy.

\section{DISCUSSION}

Leiomyoma is the most common benign esophageal neoplasm. The incidence is variable, and in autopsy series it ranges from 0.005 to $5.1 \%(1,2)$. Epidemiologically, the various series found it more frequent in men, with a 2:1 ratio, with a peak of incidence in the $3-5^{\text {th }}$ decade of life (1-3). In our series the tumor was more frequent in men (56 vs. $44 \%)$, and mean age (53.5 years) was similar to that described in the literature.

Leiomyoma is a smooth muscle cell tumor that develops predominantly intramurally and in the lower third of the esophagus (56\%) (1-3). Our results confirm these affirmations, because all of them were intramural, most were in the lower third (56\%) and middle third (33\%), and mean size was smaller than $5 \mathrm{~cm}$ (approximately $3.4 \mathrm{~cm}$ ).

Clinically, they are slow-growth tumors, most of them asymptomatic (15-50\%), and their diagnosis is followed during a long period. Interestingly there appears to be no direct correlation between tumor size and symptoms (13 ). In our series, not surprisingly most patients had gastroesophageal reflux symptoms (56\%), as these tumors are associated with esophageal disorders (hiatal hernia, gastroesophageal reflux, achalasia, epiphrenic diverticulum), and primarily with hiatal hernia in $4.5-23 \%$ of cases. 
Table I. Chronologic arrangement

\begin{tabular}{|c|c|c|c|c|c|}
\hline Esophageal leiomyoma & Case 1 & Case 2 & Case 3 & Case 4 & Case 5 \\
\hline Sex & Woman & Woman & Man & Man & Man \\
\hline Age & 70 years & 53 years & 43 years & 53 years & 51 years \\
\hline Tumor localization & Distal & Distal & Distal & Middle & Middle \\
\hline Symptoms & $\begin{array}{l}\text { Retrosternal pain, } \\
\text { anemia, melena }\end{array}$ & Duodenal ulcus & $\begin{array}{l}\text { Retrosternal pain, } \\
\text { heartburn }\end{array}$ & Rectorrhagia & $\begin{array}{l}\text { Retrosternal pain, } \\
\text { heartburn }\end{array}$ \\
\hline Diagnosis & $\begin{array}{l}\text { Oral endoscopy, } \\
\text { barium swallow, } \\
\text { abdominal ecography }\end{array}$ & $\begin{array}{l}\text { Oral endoscopy, } \\
\text { barium swallow, } \\
\text { CT scan }\end{array}$ & $\begin{array}{l}\text { Barium swallow, } \\
\text { abdominal ecography }\end{array}$ & $\begin{array}{l}\text { Oral endoscopy, } \\
\text { barium swallow, } \\
\text { breathe function test, } \\
\text { endoscopy } \\
\text { ultrasonography }\end{array}$ & $\begin{array}{l}\text { Oral endoscopy, } \\
\text { barium swallow CT scan, } \\
\text { breathe function test, } \\
\text { manometry }\end{array}$ \\
\hline Previous biopsy & None & Yes & None & Yes & None \\
\hline Procedure & Laparotomy & Thoracotomy & Laparotomy & Thoracotomy & Thoracotomy \\
\hline Surgical technique & $\begin{array}{l}\text { Mucosa OK } \\
\text { Muscular layer sutured } \\
\text { D'or }\end{array}$ & $\begin{array}{l}\text { Mucosa OK } \\
\text { Muscular layer sutured }\end{array}$ & $\begin{array}{l}\text { Mucosa OK } \\
\text { Muscular layer sutured } \\
\text { Cholecistectomy } \\
\text { D'or }\end{array}$ & $\begin{array}{l}\text { Mucosa OK } \\
\text { Muscular later sustured }\end{array}$ & $\begin{array}{l}\text { Mucosa OK } \\
\text { Muscular layer sutured } \\
\text { Prove integrity mucosa } \\
\text { with air }\end{array}$ \\
\hline Operation time & Unknown & $205 \min$ & $70 \mathrm{~min}$ & $165 \min$ & $145 \min$ \\
\hline Tumor size & $1 \times 1 \times 1 \mathrm{~cm}$ & $6 \times 4 \times 4 \mathrm{~cm}$ & $1 \times 0.8 \times 0.4 \mathrm{~cm}$ & $2.5 \times 1 \mathrm{~cm}$ & $2.5 \times 1.5 \mathrm{~cm}$ \\
\hline Postoperative hospital stay & 8 days & Unknown & 7 days & 7 days & 6 days \\
\hline Intraoperative complications & None & None & None & None & None \\
\hline Evolution & Intestinal obstruction & OK & OK & OK & $\begin{array}{l}\text { Persistent } \\
\text { ERG-surgery }\end{array}$ \\
\hline
\end{tabular}

\begin{tabular}{|c|c|c|c|c|}
\hline Esophageal leiomyoma & Case 6 & Case 7 & Case 8 & Case 9 \\
\hline Sex & Woman & Woman & Man & Man \\
\hline Age & 70 years & 56 years & 40 years & 46 years \\
\hline Tumor localization & Distal & Distal & Middle & Proximal/middle \\
\hline Symptoms & $\begin{array}{l}\text { Heartburn, postprandial } \\
\text { distension, nocturnal ERG }\end{array}$ & $\begin{array}{l}\text { Heartburn, regurgitation, } \\
\text { dysphagia, retrosternal pain }\end{array}$ & Ocasional dysphagia & Heartburn, ERG, cough \\
\hline Diagnosis & $\begin{array}{l}\text { Oral endoscopy } \\
\text { pH-metry, barium swallow }\end{array}$ & $\begin{array}{l}\text { Oral endoscopy, } \\
\text { barium swallow, manometry, } \\
\text { abdominal ecography }\end{array}$ & $\begin{array}{l}\text { Oral endoscopy, CT scan, } \\
\text { barium swallow, breathe } \\
\text { functional test, } \\
\text { transesophageal ecography }\end{array}$ & $\begin{array}{l}\text { Oral endoscopy, barium } \\
\text { swallow, CT scan, breathe } \\
\text { functional test, manometry, } \\
\text { pH-metry, endoscopy } \\
\text { ultrasonography }\end{array}$ \\
\hline Previous biopsy & None & None & None & Yes \\
\hline Procedure & Laparoscopy & Laparoscopy & Thoracoscopy & Thoracoscopy \\
\hline Surgical technique & $\begin{array}{l}\text { Mucosa OK } \\
\text { Muscular layer sutured } \\
\text { Nissen }\end{array}$ & $\begin{array}{l}\text { Mucosa OK } \\
\text { Muscular layer sutured } \\
\text { D'or } \\
\text { Prove integrity mucosa with } \\
\text { metilene blue }\end{array}$ & $\begin{array}{l}\text { Mucosa OK } \\
\text { Muscular layer sutured } \\
\text { Intraoperative endoscopy }\end{array}$ & $\begin{array}{l}\text { Mucosa OK } \\
\text { Muscular layer sutured } \\
\text { Intraoperative endoscopy }\end{array}$ \\
\hline Operation time & Unknown & $165 \min$ & $255 \mathrm{~min}$ & $270 \mathrm{~min}$ \\
\hline Tumor size & $6 \times 4 \times 3 \mathrm{~cm}$ & $8 \times 1 \mathrm{~cm}$ & $1 \times 1 \times 1 \mathrm{~cm}$ & $2 \times 2.5 \mathrm{~cm}$ \\
\hline Postoperative hospital stay & 2 days & 4 days & 4 days & 3 days \\
\hline Intraoperative complications & None & None & None & None \\
\hline Evolution & OK & OK & Right hemithorax pain & $\begin{array}{l}\text { Biliary colic and persistent } \\
\text { ERG - surgery }\end{array}$ \\
\hline
\end{tabular}


We found an associated hiatal hernia in a $44 \%$ of cases. Other symptoms are dysphagia (33\%) and retrosternal pain (33\%), but no case of weight loss was seen.

The definitive diagnosis of these tumors can be made only by histologic examination. Biopsy before surgery, from our standpoint, would be contraindicated $(3,4)$. This procedure involves risks such as secondary infection, bleeding, and esophageal mucosal perforation. In our series three biopsies were obtained (33\%), and none of them was important for the diagnosis, since histology showed a normal esophageal mucosa.

One study found that mucosal tears occurred in $50 \%$ of patients undergoing a preoperative biopsy $(1,3,5)$, and in only $8 \%$ of those who did not.

Multiple studies are available to diagnose this kind of tumors $(1,3)$; however, the two studies to be performed in all patients are, in our view, barium swallow and oral endoscopy. Thoracoabdominal CT and endoscopic ultrasonography are also interesting, as they may depict the anatomical relations of the tumor, and differentiate between intramural and extrinsec lesions.

The treatment of these tumors is controversial. There is a general consensus in the literature that esophageal leiomyoma should be surgically removed in symptomatic patients. The main problem arises when the diagnosis is made in an asymptomatic patient, which occurred in 50\% of our cases.

Overall we agree with most authors on the surgical indications of these tumors $(1,5)$ : unremitting symptoms, increased tumor size, mucosal ulceration, histopathologic diagnosis, and facilitation of other surgical procedures.

Glaz and Grunebaum (6) recommended that asymptomatic and mildly symptomatic patients should not undergo surgery but be regularly monitored using radiography and endoscopy every 1-2 years instead.

The rationale for non-surgical therapy is: the slow growth of these tumors, rare malignant transformation, and the trauma of surgical treatment may be more harmful to the patient than no treatment in any case (1).

Surgical enucleation has traditionally been the treatment of choice for these tumors, because it was an easier and faster procedure (1-10). In our hospital, all tumors were enucleated and we performed no esophageal resection, with no intraoperative complications.

The surgical approach has classically been thoracotomy. With this procedure we obtained a highly successful outcome and a low complications rate; however, we think that with the advent of laparoscopic techniques, the current surgical approach should be laparoscopic, as we obtained: a) short postoperative hospital stay (in our series, $3.25 \mathrm{vs}$. 7 days); b) decreased postoperative pain (however, in our experience, one patient with postoperative complications had undergone a thoracoscopic approach and has trocar-induced intercostal neuralgia, requiring treatment by the Pain Unit); and c) a rapid and full re-expansion of the lung $(4,8)$. Other authors $(1,8)$ recommended that the thoracoscopic approach may best be suited for use in patients with lesions smaller than $5 \mathrm{~cm}$, and when the preoperative workup has excluded malignancy.

Bonavina considers that the thoracoscopic approach would not be indicated for distal tumors if we are going to associate an antireflux technique. In these cases the abdominal laparoscopic approach would be indicated.

There are other forms of minimally invasive treatment, as the combination of endoscopy with balloon dilator assistance. When the balloon is intraluminally inflated, it promoted the expulsion of the tumor from the esophageal wall, thus facilitating thoracoscopic resection; however, there are few cases described in the literature with unreported complications and mortality $(11,12)$.

Another technique performed in Eastern countries is an endoscopic approach alone. This is generally indicated for submucosal tumors. After separating the tumor from the submucosal layer by injection of a hypertonic solution containing $10 \%$ glycerol, $5 \%$ fructose, and saline, the tumor is suctioned into a cylinder (13-17). However, we have no experience with both treatments.

Esophageal resection would be only indicated for high tumors $(>8 \mathrm{~cm})$, annular morphology, multiple leiomyomatosis, or when accidental extensive damage to the esophageal wall appears to pose a risk for postoperative leakage. We have no case of esophageal resection in our series (1), although we are experienced thereupon.

We used endoscopy intraoperatively in two cases to facilitate tumor localization.

We had no case of mucosal perforation. We do not systematically prove mucosal integrity, but for one case we used methylene blue and for another case insuflated air via a nasogastric tube.

There is some disagreement in the literature about whether myotomy should be sutured after enucleation. Hennessy and Cushieri (18) state that a wide breach can be left open without concern, but most experts $(1,3,4,8)$ emphasize the need to reapproximate the muscular wall to prevent mucosal bulging. We used vicryl or ethibond to suture myotomy. It is thought that an approximation of muscle borders after enucleation may preserve the esophageal propulsive activity, thus preventing such complications and improving long-term surgical treatment outcomes.

Several studies have reported the occurrence of postoperative dysphagia due to pseudodiverticular mucosal bulging at the enucleation site in patients in whom muscle edges were not approximated $(3,8)$.

As I have previously explained, we obtained good results with no mortality, reconversion, or intraoperative complications.

One criticism may be that two patients had to be operated on a few months after surgery for persistent symptoms of gastroesophageal reflux that had started before enucleation, as we could have associated an antirreflux technique during the first surgery. Probably, the association of an antirreflux technique could be indicated in patients undergoing enucleation to protect the muscular my- 
otomy borders and to treat gastroesophageal reflux, but this point remains highly controversial (3).

\section{CONCLUSION}

-Enucleation is an easy procedure and the treatment of choice for leiomyioma.

- The approach should be currently laparoscopic.

-We think that muscular borders should be closed, and that biopsy is not indicated before surgery.

\section{REFERENCES}

1. Lee LS, Sinighal S, Brinster CJ, Marshall B, Kochman ML, Kaiser LR, et al. Current management of esophageal leiomyoma. J Am Coll Surg 2004; 198 (1): 136-46.

2. Seremetis MG, Lyons WS, De Guzman VC, Peabody J. Leiomyomata of the esophagus. An analysis of 838 cases. Cancer 1976; 38: 2166-77.

3. Bonavina L, Segalin A, Rosati R, Pavanello M, Peracchia A. Surgical therapy of esophageal leiomyoma. Journal of American College of Surgeons 1995; 181: 257-62.

4. Van der Peet DL, Berends FJ, Klinkenberg-Knol EC, Cuesta MA. Endoscopic treatment of benign esofagueal tumors: case report of three patients. Surg Endosc 2001; 15 (12): 1489.

5. Von Rahden BHA, Stein HJ, Feussner H, Siewert JR. Enucleation of submucosal tumors of the esophagus:minimally invasive versus open approach. Surg Endosc 2004.

6. Glanz I, Grunebaum M. The radiological approach to leiomyoma of the oesophagus with a long-term follow up. Clin Radiol 1977; 28: 197-200.
7. Roviaro GC, Maciocco M, Varoli F, Rebuffat C, Vergani C, Scardue1 li A. Videothoracoscopic treatment of esophageal leiomyoma. Tho$\operatorname{rax} 1$ 1998; 53: 190-2.

8. Bardini R, Asolati M. Thoracoscopic resection of benign tumours of the esophagus. Int Surg 1997; 82: 5-6.

9. Pross M, Manger T, Wolff S, Kahl S, Lippert H. Thoracoscopic enucleation of benign tumors of the esophagus under simultaneous flexible esophagoscopy. Surg Endosc 2000 14: 1146-8.

10. Samphire J, Nafteux P, Luketich J. Minimally invasive technique for resection of benign esophageal tumors. Semin Thorac Cardiovasc Surg 2003; 15 (1): 35-43.

11. Mafune K, Tanaka Y. Thoracoscopic enucleation of an esophageal leiomyoma with balloon dilator assistance. Surg Today 1997; 27: 18992.

12. Izumi Y, Inoure H, Endo M. Combined endoluminalintracavitary thoracoscopic enucleation of leiomyoma of the esophagus. A new method. Surg Endosc 1996; 10: 457-8.

13. Kajiyama T, Sakai M, Torii A. Endoscopic aspiration lumpectomy of esophageal leiomyomas derived from the muscularis mucosae. Am J Gastroenterol 1995; 90: 417-22.

14. Eda Y, Asaki S, Yamagata L. Endoscopic treatment for submucosal tumors of the esophagus: studies in 25 patients. Gastroenterol Jpn 1990; 25: 411-6.

15. Wehrmann T, Martchenko K, Nakamura M, Riphaus A, Stergiou N. Endoscopic resection of submucosal esophageal tumors: a prospective case series. Endoscopy 2004; 36: 802-7.

16. Park YS, Park SW, Kim TI, Song SY, Choi EH, Chung JB, et al. Endoscopic enucleation of upper-GI submucosal tumors by using an insulated-tip electrosurgical Knife. Gastrointes Endosc 2004; 59 (3): 409-15.

17. Hyun JH, Jeen YT, Chun HJ, Lee HS, Lee SW, Song CW, et al. Endoscopic resection of submucosal tumor of the esophagus: results en 62 patients. Endoscopy 1997; 29 (3): 165-70.

18. Hennesey TPJ, Cushieri A. Tumors of the oesophagus. In: Hennesey TPJ, Cushieri A, editors. Surgery of the oesophagus. London: Butterworth-Heinemann; 1992. p. 275-327. 
Resultados: la estancia hospitalaria postoperatoria oscila entre los 2-8 días, con una media de 5,12 días, siendo esta menor en el grupo en el que se realizó cirugía laparoscópica en comparación con el grupo de cirugía abierta (3,25-7 días). No existe ningún caso de perforación de la mucosa esofágica ni de reconversión. Tampoco se describe ningún caso de mortalidad, complicación intraoperatoria ni de recidiva tumoral. Dos pacientes presentan algún tipo de complicaciones: dolor torácico post cirugía, obstrucción intestinal por bridas 8 años después de la cirugía.

Conclusión: la enucleación es un procedimiento fácilmente realizable y constituye el tratamiento de elección del leiomioma esofágico. Actualmente el abordaje debe ser laparoscópico. Somos partidarios del cierre de la muscular y bajo nuestro punto de vista la biopsia preoperatoria no está indicada.

Palabras clave: Leiomioma esofágico. Enucleacion. Toracoscopia. Laparoscopia. Toracotomía. Tumor benigno.

\section{INTRODUCCIÓN}

El leiomioma es la neoplasia benigna más frecuente del esófago. Su incidencia es variable, y en las diferentes series basadas en necropsias, oscila en torno a un 0,005-5,1\%. A pesar de estos valores, su incidencia es relativamente rara cuando se compara con el carcinoma esofágico que es 50 veces más frecuente.

La primera descripción de un leiomioma fue realizada por Morgagni en 1761, sin embargo fue Munro quien describió por primera vez un leiomioma esofágico de localización intramural.

Tradicionalmente se han incluido a los leiomiomas dentro del grupo de los tumores del estroma gastrointestinal (GIST), sin embargo, los avances en el campo de la inmunohistoquímica y la biología molecular han demostrado que son dos entidades diferentes.

Los síntomas en general son inespecíficos y de larga duración, siendo la enucleación el tratamiento de estos tumores aunque controvertido.

Sauerbruch describió en 1932 el primer caso de leiomioma esofágico intervenido quirúrgicamente mediante resección esofágica, y un año después, Ohsawa describió la primera enucleación exitosa como tratamiento en este tipo de tumores.

El tratamiento quirúrgico se ha realizado tradicionalmente por medio de una laparo- o toracotomía. Sin embargo, el auge de las técnicas mínimamente invasivas, ha favorecido a que, en la actualidad, la enucleación del leiomioma se realice por medio de un abordaje laparoscópico.

El objetivo de este trabajo es el de efectuar un análisis retrospectivo de la experiencia de nuestro hospital en este tipo de patología, efectuando una comparación entre los resultados obtenidos por vía abierta y laparoscópica.

\section{MATERIAL Y MÉTODOS (Tabla I)}

Entre 1986 y 2004 se han intervenido en el Hospital Ramón y Cajal un total de 9 casos de leiomioma esofági- co. Encontramos a 4 mujeres (44\%) y a 5 varones $(56 \%)$, con edades comprendidas entre los 40 y los 70 años, siendo la edad media de 53,5 años.

Desde el punto de vista anatomopatólogico, 5 de ellos se localizaban en el tercio distal del esófago (56\%), 3 en el tercio medio (33\%) y 1 en el tercio superior $(11 \%)$.

El tamaño oscila entre $1-8 \mathrm{~cm}$, siendo la media de $3,4 \mathrm{~cm}$. No hubo ningún caso de leiomioma múltiple y todos tuvieron una localización intramural.

El diagnóstico anatomopatológico definitivo fue en todos los casos de leiomioma esofágico, excepto en un caso que es un quiste de duplicación esofágico. Se observa el típico aspecto de los leiomiomas de consistencia firme, bien encapsulado, de superficie lisa o nodular y color blanquecino. Microscópicamente se observan células musculares lisas con hipovascularización y ausencia de mitosis.

Los principales síntomas fueron pirosis en 5 casos (56\%), disfagia en $3(33 \%)$ y dolor epigástrico-retroesternal en otros 3 casos (33\%). Dos pacientes presentaban clínica de hemorragia digestiva alta (melenas y ulcus duodenal), 1 de ellos refería regurgitación y otro rectorragia. Solamente se encontraban asintomáticos 2 pacientes (ulcus duodenal y rectorragia), lo que supone una tasa de pacientes asintomáticos del 22,2\%, además en otro de los casos se realiza el diagnóstico intraoperatorio en el transcurso de una cirugía antirreflujo.

En cuanto a las pruebas complementarias realizadas de forma previa a la cirugía, tenemos: endoscopia oral 8/9 (88,8\%), EGD 9/9 (100\%), TAC toracoabdominal $4 / 9(44,4 \%)$, pruebas de función respiratoria 4/9 $(44,4 \%)$ fundamentalmente en aquellos casos en los que se va a realizar un abordaje torácico (toracotomía y toracoscopia), ecoendoscopia 3/9 (33\%), ecografía abdominal 3/9 (33\%), manometría 3/9 (33\%) y pH-metría 2/9 (22,2\%).

En 3 pacientes se va a realizar biopsia de forma previa a la cirugía, no encontrándose tumor en ninguna de ellas. En dos casos se realizará mediante ecoendoscopia y en un caso mediante TAC + punción.

Cuatro pacientes presentaban a su vez una hernia de hiato $(44,4 \%)$ como trastorno esofágico asociado.

En cuanto a la vía de abordaje utilizada, tenemos 3 casos de toracotomía, 2 de laparotomía, 2 de toracoscopia y 2 mediante laparoscopia (5 procedimientos abiertos y 4 laparoscópicos). Si realizamos el recuento a partir del año 2000, vemos el aumento en la utilización de la cirugía mínimamente invasiva, pues 4 de ellos se van a relizar vía endoscópica y 1 por toracotomía.

En los abordajes torácicos se realiza la intubación con un tubo endotraqueal de doble luz, el paciente se coloca en decúbito lateral izquierdo, y se suelen utilizar 4 trócares para abordar la cavidad pleural.

En el abordaje laparoscópico abdominal seguimos los mismos principios establecidos para cualquier cirugía del hiato esofágico. 